УДК 338.43

DOI: https://doi.org/10.37320/2415-3583/13.2

Слюсаренко А.В.

кандидат економічних наук,

Миколаӥвський національний аграрний університет ORCID: https://orcid.org/0000-0001-7116-5783

\title{
НЕОБХІДНІСТЬ ДЕРЖАВНОГО РЕГУЛЮВАННЯ ЗОВНІШНЬОЕКОНОМІЧНОЇ БЕЗПЕКИ ПІДПРИЕМСТВ АГРАРНОГО СЕКТОРУ
}

\begin{abstract}
У статті проведено визначення галузевих особливостей регулювання та гарантування зовнішньоекономічної безпеки аграрного сектору загалом та його підприємств зокрема. Здійснено обтрунтування необхідності регуляторного впливу з боку держави в силу аграрного иентризму розвитку національної економіки та чільності сільського господарства в системі начіональної та продовольчої безпеки України. Актуалізовано дочільність оновлення діючих підходів забезпечення високих безпекових показників для підприємств аграрної сфери в силу посилення інтеграиійних процесів та глобалізації в умовах реалій сьогодення. Проаналізовано твердження щзодо недосконалості ринку як єдиного й абсолютного регулятора з актуалізачією доиільності втручання з боку держави в процес функиіонування та розвитку діючих суб'єктів аграрного підприємництва. Визначено нагальну необхідність державного регуляторного впливу та захисту інтересів вітчизняних аграрних товаровиробників у силу системності підвищення експортно-імпортної активності та представленості продукцї̈ українського виробництва на зовнішніх ринках.
\end{abstract}

Ключові слова: зовнішньоекономічна безпека, аграрний сектор, економічний розвиток, експорт, iмnорт, ринок, глобалізаџія.

Постановка проблеми. Через значущість результуючих функціонування аграрного сектору для української економіки варто зважити на необхідність відповідного державного регулювання та окреслення специфічних галузевих особливостей. Сільське господарство становить основу продовольчої та національної безпеки держави, що виокремлює його з-поміж інших сфер діяльності в структурі економіки України. Окрім того, сектор є одним із основних у формуванні валового внутрішнього продукту, є бюджетоутворюючим та сприяє розвитку інших галузей. Незважаючи на виключну важливість сільського господарства, відсутнім $€$ відповідне аграрне законодавство та механізми гарантування економічної безпеки сектору загалом та підприємств зокрема, які би враховували весь спектр галузевих особливостей. Більш того, фактичним $є$ збільшення експортно-імпортної активності діючих суб'єктів аграрного підприємництва, що вимагає розроблення відповідних механізмів гарантування зовнішньоекономічної безпеки з боку держави.

Аналіз останніх досліджень і публікацій. В умовах поглиблення інтеграційних процесів та посилення впливу глобалізації на українську економіку загалом та аграрний сектор зокрема спостерігається підвищення зовнішньоекономічної активності вітчизняних товаровиробників сільськогосподарської продукції, що супроводжується актуалізацією питань безпеки 3 боку науковців та практиків сьогодення. Проблемам зовнішньоекономічної безпеки аграрного сектору на макрорівні присвячені праці таких науковців, як В.І. Аранчій, В.І. Криленко, Н.В. Ботова, Н.П. Дубова, А.П. Макаренко та ін. Нині досить дослідженими є питання державного регулювання зовнішньоекономічної безпеки України, що підтверджується широким колом наукових праць у цьому напрямі. Проте донині не досить обгрунтованими та дослідженими залишаються питання гарантування безпекових характерис- тик зовнішньоекономічної діяльності сільськогосподарських підприємств із боку держави, що породжує низку проблем загальнонаціонального масштабу та передує наявності вад у системі розвитку національної економіки.

Формулювання цілей статті (постановка завдання). Метою статті є обгрунтування особливостей та необхідності державного управління зовнішньоекономічною безпекою підприємств аграрного сектору.

Виклад основного матеріалу дослідження. Аграрний сектор набуває виключної ваги в силу центризму в системі продовольчого забезпечення зокрема та сільськогосподарської спрямованості економічного розвитку України загалом. Н.В. Батова слушно зауважує, що сільське господарство в економіці будь-якої країни, займає особливе місце і має низку особливостей. До основних особливостей авторка відносить те, що виробництво сільськогосподарської продукції органічно пов'язане з використанням землі і природного середовища, при цьому земля є головним засобом виробництва [1, с. 540]. О.Л. Попова під час формування висновків стосовно важливості сільського господарства та необхідності гарантування його економічної та зовнішньоекономічної безпеки зазначає, що саме аграрне виробництво здійснює безпосередній вплив на економіку та соціальні відносини країни загалом, а також визначає стан навколишнього середовища, а отже, й екологічної безпеки [2, с. 91]. Тож дійсно аграрний сектор відіграє значну роль в структурі національної економіки і при цьому має низку особливостей, які актуалізують питання розроблення механізмів гарантування зовнішньоекономічної безпеки з боку держави як на макро-, так і на мікрорівні.

У контексті тематики дослідження варто прийняти до уваги висловлювання Н.П. Дубової, яка зазначає, що глобальною тенденцією світового економічного розвитку є посилення економічної ролі держави, зрос- 
тання обсягів і багатоаспектності їі діяльності. Дійсно, попри популяризацію і розповсюдженість глобалізації, лібералізації та ринкових умов, передові економіки країн світу схиляються в своїй практиці до запровадження чітких позицій державного контролю, що підтверджується зниженням у значеннях їхніх рівнів економічної глобалізації. Наукові трактування сучасників виправдано формують висновок стосовно того, що наявні соціально-економічні системи та моделі економіки є все більше одержавленими через збільшення рівня контролю з боку держави, хоча і залишаються ринковими. Ефективність сучасної економіки загалом та в розрізі галузей є неможливою як без функціональної самостійності підприємств, так і без чіткого державного регулювання [3, с. 9]. Попри світові тренди, які мають місце в досвіді передових країн світу, зовнішньоекономічна діяльність України значною мірою лібералізована без опанування державою відповідних контрольно-регулюючих функцій та врахування специфіки перехідного періоду, що створює неабияку загрозу вітчизняній економічній, а отже, й зовнішньоекономічній безпеці [4, с. 154].

B.I. Криленко у своїх дослідженнях зазначає, що цивілізованість держави виявляється не тільки у високому рівні культури життя, але й у культурі використання регуляторної політики та управління державною діяльністю, що будується на реалізації довгострокових і раціональних стратегічних цілей розвитку [5, с. 258]. Дійсно, стратегічна функціональна єдність суб'єктів підприємницької діяльності досягається за рахунок регулюючого впливу з боку держави. До того ж національна безпека $є$ логічним та комплексним процесом, який вимагає узгодженості дій на мікрорівні через чіткість регуляторної політики на макрорівні. У контексті аграрного сектору автор зазначає, що використання регуляторної політики держави 3 метою управління його безпекою через цілеспрямоване створення системи іiі забезпечення є вищим рівнем безпечного менеджменту.

Українське сьогодення та умови практичної дійсності аграрного бізнесу вимагають посилення заходів гарантування економічної та зовнішньоекономічної безпеки сільськогосподарських підприємств, що першочергово зумовлено високим рівнем галузевих ризиків в діяльності та нестабільністю їхнього функціонування. Нині аграрний сектор є чи не єдиним, який має позитивне значення експортно-імпортної діяльності. 3 роками обсяги експортної активності підприємств зростають, і сільське господарство підтверджує стратегічну аграрну спрямованість розвитку української економіки, виступаючи іiї драйвером та акселератором. Проте, попри зростання обсягів експорту українських товаровиробників аграрної продукції, невирішеними залишаються питання вирівнювання функціональних можливостей їх на міжнародному ринку в порівнянні 3 потужними світовими корпораціями. Недосконалими $\epsilon$ механізми гарантування зовнішньоекономічної безпеки підприємств аграрного сектору. Формуванню державного механізму гарантування та регулювання зовнішньоекономічної безпеки, який був би відповідним вимогам ринкової економіки та передбачав необхідність розвитку підприємництва в аграрному секторі, приділено недостатньо уваги з боку вітчизняної наукової еліти. Наслідковими є проблеми низької конкурен- тоспроможності національного аграрного виробника та тінізація зовнішньоекономічної діяльності.

Першочергово під час проведення досліджень за визначеною тематикою необхідно зважити на дуальність природи зовнішньоекономічної безпеки аграрних підприємств [6]. Загалом державна економіка $є$ соціально-економічною системою складного типу, яка представлена більшпю мірою саме суб'єктами підприємницької діяльності як основними формувачами валового внутрішнього продукту, тобто основного економічного масиву потужності національної економіки. За замовчуванням аграрні підприємства, як і весь діючий вітчизняний бізнес, є системами відкритого типу, які вільні у визначені економічної політики та стратегії, виборі постачальників, організації виробництва та збуту і несуть індивідуальну відповідальність за результати господарської діяльності. Проте водночас вони є практично підпорядкованими в сенсі функціонування і розвитку системам вищого рівня, а саме державі в сукупності інституцій та органів управління. Тож державне регулювання зовнішньоекономічної безпеки сільськогосподарських підприємств є сутнісно та логічно складним механізмом, який має враховувати широкий спектр інтересів як окремо взятої соціально-економічної системи, тобто підприємства, так і держави загалом. Взагалі це і визначає необхідність державного втручання в процес функціонування аграрного бізнесу, адже лише держава в змозі шляхом безпосереднього та опосередкованого впливу через сукупність важелів та методів досягти виваженої гармонійної, консенсусної політики, яка гарантуватиме узгодження норм національної безпеки та інституту аграрного підприємництва.

Нині одним із ключових факторів необхідності формування державної регуляторної політики зовнішньоекономічної безпеки є недосконалість ринку як практичного процесу, для якого характерні саморегуляція та самоорганізація. У планетарному масштабі мають місце маніпулювання та деструктивні впливи крізь призму пропаганди глобалізації та лібералізації міждержавних відносин як основних засобів досягнення високих рівнів економічного розвитку. Необхідно зважати на досконалість, самодостатність та потужність економічної системи тієї чи іншої держави та її готовність до участі в рівних умовах конкурентоспроможності на світовому ринку. Потужні держави 3 розвиненими економіками мають можливість деструктивного впливу на менш розвинені економіки з подальшою експансією їхніх ринків та відкриттям доступу до необхідного ресурсного потенціалу, таким чином перетворюючи економіку останніх в сировинну з низьким рівнем доданої вартості.

Варто погодитись 3 твердженням О.П. Макаренка, який зазначає, що ринок як стихійний регулятор не $\epsilon$ ідеальним. Він слушно зауважує, що є безліч проблем, пов'язаних зі специфікою сільського господарства, які ринок не може вирішити, а саме ефективного та збалансованого використання грунтів 3 позицій збереження їхніх якісних властивостей, а також врахування природних факторів впливу, які не є підконтрольними і прогнозованими [7]. Ринок не в змозі враховувати специфіку аграрної галузі та нівелює соціальний ефект, який формує підгрунтя продовольчої, економічної та національ- 
ної безпеки. Під час визначення недосконалості ринку варто зауважити на противажності державного впливу, який спрямований на упередження і усунення негативних або ж деструктивних наслідків його впливу. Тобто пропонується підхід, який передбачає асоціювання державного регулювання як доповнення ринкового механізму саморегуляції. Взагалі удосконалення державного регулювання, яке здатне заперечувати негативні наслідки з боку світового ринку, недержавних та наднаціональних інституцій, стало б запорукою гарантування зовнішньоекономічної безпеки підприємств аграрного сектору. Ринкова економіка $є$ стихійною й обмежено керованою за своєю природою, а отже держава крізь призму визначених важелів, які формують аграрну політику, має досягати балансу кількісних та якісних параметрів системи, урівноважувати їх.

Проте, попри визначення недосконалості ринку як одного $з$ ключових факторів необхідності державного втручання в діяльність суб'єктів аграрного підприємництва, головним заданням останнього $€$ не боротьба $з$ наслідками впливу першого, а досягнення його об'єктивності, прозорості, демократизму, функціональної прийнятності в сенсі конкурентоспроможності. Тож державна політика сприяння зовнішньоекономічній безпеці підприємств аграрного сектору економіки України має бути спрямованою на коригування торговельних відносин на міжнародному рівні 3 метою захисту інтересів національних товаровиробників, їх підтримки та сприяння планомірному розвитку.

Додатковим фактором, який слугує на користь необхідності негайного перегляду діючої державної регуляторної політики в аграрному секторі, є зміни стратегічних орієнтирів партнерства України. Маємо справу зі змінами політичної та економічної ситуації, тенденцій розвитку міжнародної торгівлі на світовому рівні в силу якісних змін в економічних системах передових країн світу. Саме тому сьогодні на державу покладено функції формування інноваційних пріоритетів та стратегій розвитку зовнішньоекономічної діяльності з метою своєчасних і адекватних реакцій на зміни та трансформації в глобальному економічному просторі. Головною ціллю є досягнення узгодженості та компромісу між стратегіями розвитку держави та діючих суб'єктів підприємницької діяльності в сільському господарстві.

Під час проведення досліджень доцільно звернути увагу на той факт, що останніми роками структура українського експорту має такий розподіл за товарними групами: товари проміжного споживання становлять близько $80 \%$, готова продукція - 10\%, засоби виробництва - 10\%. Експорт високотехнологічної продукції становить близько 5\%, тоді як частка цієї продукції в практиці розвинених країн сягає 15\%. На противагу у структурі аграрного імпорту переважають готова продукція та товари виробничого призначення. Таким чином, реальні фактичні дані підтверджують недосконалість регуляторного впливу з боку держави в контексті імпортної безпеки аграрного сектору. Загалом зазначенні структури експорту та імпорту аграрної продукції $є$ загрозою для зовнішньоекономічної безпеки держави. Тож одним 3 ключових завдань і проблем державного регулювання зовнішньоекономічної безпеки сільськогосподарських підприємств є оптимізація зовнішньоторговельної товарної структури, яка би передбачала збільшення частки готової продукції в експорті та зменшення частки паливних матеріалів, засобів виробництва, насіннєвих матеріалів та засобів захисту і догляду за сільськогосподарськими культурами, екологічно шкідливої і неякісної продукції, а також товарів широкого вжитку в імпорті.

Варто брати до уваги той факт, що в контексті зовнішньоекономічної безпеки підприємств аграрного сектору під час регулювання експортно-імпортних операцій держава повинна сприяти розвитку прозорої конкуренції як на внутрішньому так і на зовнішньому ринках, реалізуючи при цьому відповідну політику, яка має бути адекватною потребам та інтересам вітчизняних товаровиробників сільськогосподарської продукції та послуг. Державна регуляторна політика зовнішньоекономічної безпеки аграрного сектору загалом та підприємств зокрема передусім має бути націленою на гарантування та захист інтересів національних та вітчизняних суб'єктів підприємницької діяльності. Вона повинна сприяти формуванню раціональної структури експорту та імпорту, а також залученню іноземних інвестицій на взаємовигідних умовах. Вплив держави не має заперечувати доступ на внутрішній ринок іноземних партнерів у сфері аграрного виробництва 3 метою заохочення конкуренції та протидії монополізації, сприяння структурним та технологічним змінам у межах сектору. Проте через виваженість регуляторної політики мають створюватись сприятливі для українських сільськогосподарських товаровиробників позиції на світовому продовольчому ринку. Такий підхід є можливим у разі обгрунтованого компромісного національного бачення розвитку інституту аграрного підприємництва на внутрішньому та світовому ринках, оцінці позитивного й негативних ефектів від участі в світовій торговельній діяльності. Зважаючи на це, під ефективним державним регулюванням зовнішньоекономічної безпеки підприємств аграрного сектору України слід розуміти застосування такої регуляторної політики з боку держави, яка би сприяла створенню взаємовигідних економічних відносин для українських та іноземних суб'єктів господарської діяльності, які мають місце в Україні та за їі межами й економічним середовищем яких $є$ аграрний сектор із гарантуванням рівних функціональних прав та сприянням розвитку насамперед інституту вітчизняного аграрного підприємництва без порушення принципів прозорої конкуренції та вільного ринку.

Поряд із галузевими особливостями, які формують актуальність регуляторного впливу з боку держави, необхідно звернути увагу на важелі впливу, через які реалізується власне сам механізм регулювання та координації зовнішньоекономічної безпеки сільськогосподарських підприємств. В умовах вітчизняних реалій в науці та практиці представлено широкий спектр способів та важелів, які в більшості поділяють на дві групи, а саме: адміністративно-правові та економічні [8]. Г. Гринишин у своїх працях дещо розширює приведений перелік важелів державного регулювання з виділенням фінансово-економічних, організаційно-адміністративних, інституційно-правових і соціально-психологічних методів та інструментів [9]. Ствердно можна говорити про те, що дієвість механізму державного регулювання досягається лише у разі комплексного підходу у застосуванні вищезазначених важелів. 
Маємо безліч дискусій, які присвяченні питанням пріоритетності того чи іншого підходу в державному регулюванні з позицій його дієвості. Низка науковців схиляють до думки стосовно переважання ролі фінансово-економічних методів крізь призму тарифних та нетарифних методів, а також цінових факторів. Натомість не менш представленими в науці та практиці $е$ думки стосовно важливості адміністративно-правових методів крізь призму нормативно-правового забезпечення та ефективності менеджменту. Практично виважене та науково-обгрунтоване використання усіх методів та інструментів в комплексі надає можливість державі через функціонування відповідних інституцій досягати позитивного ефекту в частині подолання економічних криз та негативних ситуацій аграрними підприємствами, які спровоковані факторами екзогенного впливу, і сприяти економічному зростанню сільськогосподарських підприємств та розвитку сектору загалом. Мета ж державного управління визначена збільшенням обсягів виробництва конкурентоспроможної сільськогосподарської продукції та послуг і представлення їх на зовнішніх ринках, зміцненням експортного потенціалу та підвищенням ефективності зовнішньоекономічної діяльності в аграрному секторі України.

Під час проведення власних досліджень доцільно зважити на трактування С. Маталки, яка визначає сутність державної регуляторної політики зовнішньоекономічної безпеки підприємств аграрного сектору як сукупності конкретних механізмів, а також системи економічних, організаційних, адміністративних, інституціональних, правових, соціально-психологічних важелів, які забезпечують ефективну взаємодію вітчизняних сільськогосподарських підприємств зі світовими народногосподарськими структурами як на мікро-, так і на макрорівні з метою прискорення розвитку експортоорієнтованої діяльності, підвищення ефективності зовнішньоекономічних операцій, гарантування продовольчої безпеки країни та покращення соціально-економічних показників життя громадян [10]. Це визначення $є$ комплексним за змістом і повною мірою розкриває сутність досліджуваного процесу, що дозволяє приймати його за основу під час проведення подальших досліджень та деталізації в розрізі конкретних способів регулювання. Загалом державна регуляторна політка зовнішньоекономічної безпеки сільськогосподарських підприємств, за влас- ними судженнями, є системою форм, методів і важелів, за допомогою яких держава, а також іiі галузеві та територіальні органи управління сприяють підвищенню ефективності функціонування підприємств аграрної сфери на внутрішньому і зовнішніх ринках в умовах конкурентної рівності.

Висновки. У підсумку наукового дослідження доречно зауважити, що українська аграрна дійсність пройшла довгий шлях функціональної незалежності від необгрунтованого оптимізму до виваженого прагматизму зі змінами аграрної політики, методів їі регулювання, векторів зовнішньоекономічного розвитку та поглядів на необхідність гарантування економічної безпеки національних товаровиробників сільськогосподарської продукції. Проте реалії сьогодення сформували стійкі позиції неолібералізму в національній економіці, в тому числі й в аграрному секторі, який передбачає розширення меж міждержавної взаємодії і поглиблення інтеграції через зменшення протекціоністських заходів і прийняття ринкових умов в абсолютному вираженні. Проте виникає питання доцільності розвитку вітчизняного аграрного виробництва виключно на засадах ринкових відносин і якості таких відносин із погляду зовнішньоекономічної безпеки українських товаровиробників сільськогосподарської продукції та послуг. Регулювання експортно-імпортної діяльності аграрних підприємств державою $\epsilon$ нагальною потребою сучасності, адже в підсумку вирішуються проблеми гарантування продовольчої та національної безпеки загалом. Тому державне регулювання зовнішньоекономічної безпеки підприємств аграрного сектору $є$ механізмом досягнення компромісу між зисками, які отримує сільськогосподарський товаровиробник від зовнішньоекономічної діяльності, загрозами, які несе в собі ця діяльність, та відповідністю їх національним стратегічним інтересам. Державна регуляторна політика $є$ способом захисту інтересів українських аграріїв наамперед на внутрішньому ринку та сприяння їхній конкурентоспроможності на зовнішньому. Актуалізація та вирішення проблем зовнішньоекономічної безпеки сільськогосподарських товаровиробників поряд з економічною безпекою держави загалом дасть змогу сформувати потужний аграрний сектор України, який здатен приймати участь у світогосподарських відносинах на паритетних засадах із подоланням асоціативного сприйняття як сировинного.

\section{Список використаних джерел:}

1. Batova V.N., Pavlov A.J. Providing Economic Safety of Business Processes in the Conditions of Implementing the Concept of Stable Development. World Applied Sciences Journal. Pakistan, 2013. 27(4). P. 538-542.

2. Попова О.Л. Нові пріоритети Спільної аграрної політики СС на 2014-2020 роки: Стратегічні орієнтири для розвитку агросфери України. Економіка АПК. Київ, 2013. № 12. С. 89-96.

3. Дубова Н.П. Макроекономічне державне регулювання аграрної сфери економіки : автореф. дис. ... канд. екон. наук : 08.01.01. Дніпропетровськ : Дніпропетровський державний аграрний університет, 2003. 16 с.

4. Аранчій В.І. Зовнішньоекономічна безпека України в контексті міжнародної інтеграції. Вісник Полтавської державної аграрної академії. Полтава, 2012. № 2. С. 150-161.

5. Криленко В.І. Економічна безпека аграрного сектору: проблеми регулювання та забезпечення : монографія. Миколаїв : Видавець В.П. Шамрай, 2014. 468 с.

6. Живко З.Б. Економічна безпека підприємства: сутність, механізм забезпечення та управління : монографія. Львів : Львівський державний університет внутрішніх справ, 2012. 260 с.

7. Макаренко А.П. Державне регулювання розвитку аграрної сфери в ринковій економіці : автореф. дис. ... докт. екон. наук : 08.00.03. Миколаїв : Миколаївський національний аграрний університет, 2009. 44 с.

8. Козловський С.В., Кірєєва Е.А., Журавківський Є.С. Інструментарій державної аграрної політики забезпечення економічної безпеки аграрної галузі України. Економіка та держава. Київ, 2016. № 4. С. 9-14. 
9. Гринишин Г. Шляхи вдосконалення механізму зовнішньоекономічної діяльності підприємств аграрної сфери. Вісник Львівського начіонального аграрного університету. Серія : Економіка АПК. Львів, 2014. № 21(1). С. $200-206$.

10. Маталка С. Ф. Управління ефективністю зовнішньоекономічної діяльності підприємств : монографія. Луганськ : Ноулідж, 2011. 210 c.

\section{References:}

1. Batova V.N., Pavlov A.J. (2013). Providing Economic Safety of Business Processes in the Conditions of Implementing the Concept of Stable Development. World Applied Sciences Journal, vol. 27, no. 4, pp. 538-542.

2. Popova O.L. (2013). Novi priory 'tety`Spil’noyi agrarnoyi polity 'ky`YeS na 2014-2020 roky`: Strategichni oriyenty 'ry` dlya rozvy 'tku agrosfery` Ukrayiny` [New priorities of the EU Common Agricultural Policy for 2014-2020: Strategic guidelines for the development of Ukraine's agro-sphere]. Economics of agro-industrial complex, vol. 12, pp. 89-96.

3. Dubova N.P. (2003). Macroeconomic state regulation of the agrarian sphere of the economy. Candidate's thesis. Dnipropetrovsk: Dnipropetrovsk State Agrarian University. 16 p. (in Ukrainian)

4. Aranchiy V.I. (2012). Zovnishn`oekonomichna bezpeka Ukrayiny`v konteksti mizhnarodnoyi integraciyi [Ukraine's foreign economic security in the context of international integration]. Bulletin of the Poltava State Agrarian Academy, vol. 2, pp. 150-161.

5. Krylenko V.I. (2014). Ekonomichna bezpeka agrarnogo sektoru: problemy` regulyuvannya ta zabezpechennya [Economic security of the agricultural sector: problems of regulation and provision]. Mykolaiv: Publisher VP Shamrai, 468 p. (in Ukrainian)

6. Zhivko Z.B. (2012). Ekonomichna bezpeka pidpry yemstva: sutnist, mexanizm zabezpechennya ta upravlinnya [Economic security of the enterprise: essence, mechanism of maintenance and management]. Lviv: Lviv State University of Internal Affairs, $260 \mathrm{p}$. (in Ukrainian)

7. Makarenko A.P. (2009). State regulation of agricultural development in a market economy. Doktor's thesis. Mykolaiv: Mykolayiv National Agrarian University, 44 p. (in Ukrainian)

8. Kozlovsky S.V., Kireeva E.A., Zhuravkovsky E.S. (2016). Instrumentarij derzhavnoyi agrarnoyi polity`ky` zabezpechennya ekonomichnoyi bezpeky` agrarnoyi galuzi Ukrayiny` [Tools of the state agrarian policy of ensuring economic security of the agrarian branch of Ukraine]. Economy and state, vol. 4, pp. 9-14.

9. Hrynyshyn G. (2014). Shlyaxy`vdoskonalennya mexanizmu zovnishn`oekonomichnoyi diyal’nosti pidpry`yemstv agrarnoyi sfery` [Ways to improve the mechanism of foreign economic activity of agricultural enterprises]. Bulletin of Lviv National Agrarian University. Series: Economics of agro-industrial complex, vol. 21, no. 1, pp. 200-206.

10. Matalka S.F. (2011). Upravlinnya efekty vnistyu zovnishn`oekonomichnoyi diyal nosti pidpry yemstv [Management of efficiency of foreign economic activity of enterprises]. Lugansk: Knowledge, 210 p. (in Ukrainian)

Sliusarenko Andrii

Mykolayiv National Agrarian University

\section{THE NEED FOR STATE REGULATION OF FOREIGN ECONOMIC SECURITY OF AGRICULTURAL ENTERPRISES}

The agricultural sector is a major in the national economic system, despite its share in the gross national product, exports and employment. Along with the importance of agriculture to the national economy sector is the only sector that has a positive value of export-import activities. The domestic reality is characterized by a deepening of integration processes and the increasing role of globalization, as evidenced by the increasing export and import activity on the part of agricultural producers. However, in terms of increasing volumes of foreign economic activities of the regulatory policy of the state and approaches to the guaranteeing and ensuring of foreign economic security remain archaic, and not sufficiently effective in a market economy. The agricultural sector has a number of industry characteristics. which should be considered on the development of innovative approaches to state regulation of foreign economic security of enterprises, which actualizes a specific theme. The article presents the rationale of the regulatory impact of the state because of agrarian centric development of the national economy and clinet of agriculture in national and food security of Ukraine. In the context of study identifies the imperfections in the current regulatory policy through the high degree of market dependence. Substantial proven market inefficiencies with an absolute position of the controller via a leveling social factor and limited regard to local peculiarities. The state should be an alternative regulator in the formation of a high level of safety performance at the level of the market, the implementation of foreign economic activities of Ukrainian entities of agricultural production and to foster their organic development, without violating the principles and rules of healthy competition in both domestic and foreign markets. Identified the urgent need for regulatory influence and protect the interests of domestic agricultural producers because of the systematic increase of export-import activity and representation of its products in foreign markets. In case the problem is not sufficiently investigated by scholars and practitioners of our time and requires updating in the first place, from the standpoint of updating the current regulatory policy of foreign economic security of agricultural enterprises.

Key words: foreign economic security, agricultural sector, economic development, export, import, market, globalization.

JEL classification: F52, F62, H83, O13, Q17 